\title{
Lack of HLA Class I Antigen Expression by Melanoma Cells SK-MEL-33 Caused by a Reading Frameshift in $\beta_{2}$-Microglobulin Messenger RNA
}

\author{
Z. Wang, * Y. Cao, * A. P. Albino, ${ }^{*}$ R. A. Zeff, ${ }^{*}$ A. Houghton, ${ }^{*}$ and S. Ferrone* \\ ${ }^{*}$ Department of Microbiology and Immunology, New York Medical College, Valhalla, New York 10595; Department of Pathology, \\ University of Connecticut Health Center, Farmington, Connecticut 06032; and ${ }^{\S}$ Department of Immunology, \\ Memorial Sloan-Kettering Cancer Center, New York 10021
}

\begin{abstract}
The lack of HLA class I antigen expression by the melanoma cell line SK-MEL-33 is caused by a unique lesion in $\beta_{2}$-microglobulin $\left(\beta_{2}-\mu\right)$. Sequencing of $\beta_{2}-\mu$ mRNA detected a guanosine deletion at position 323 in codon 76 that causes a frameshift with a subsequent introduction of a stop codon at a position 54 base upstream of the normal position of the stop codon in the message. The loss of 18 amino acids and the change of 6 amino acids, including a cysteine at position 80 in the carboxy terminus of $\beta_{2}-\mu$, are likely to cause marked changes in the structure of the polypeptide. The latter may account for the inability of $\beta_{2}-\mu$ to associate with HLA class I heavy chains and for its lack of reactivity with the anti- $\beta_{2}-\mu$ mAb tested. HLA class $I$ antigen expression on SK-MEL-33 cells was reconstituted after transfection with a wild-type $B_{2} m$ gene, therefore indicating that the abnormality of endogenous $B_{2} m$ gene is the only mechanism underlying lack of HLA class $I$ antigen expression by SK-MEL-33 cells. The guanosine deletion in $B_{\mathbf{2}} \mathbf{m}$ gene was detected also in the melanoma tissue from which SKMEL-33 cells had originated. Therefore, the molecular lesion identified in the SK-MEL-33 melanoma cell line is not caused by a mutation acquired during growth in vitro but is likely to reflect a somatic mutation during tumor progression. (J. Clin. Invest. 1993. 91:684-692.) Key words: $\beta_{2}$-microglobulin sequencing - transfection - HLA reconstitution - monoclonal antibody
\end{abstract}

\section{Introduction}

Malignant transformation of human melanocytes may be associated with changes in their antigenic profile. The latter include reduction or loss of HLA class I antigen expression, which has been found to occur in $\sim 30 \%$ of surgically removed melanoma lesions (for review, see reference 1). Abnormalities in HLA class I antigen expression are likely to affect the biology of melanoma cells and their interactions with immune cells be-

Address correspondence to Soldano Ferrone, M.D., Department of Microbiology and Immunology, New York Medical College, Basic Sciences Building, Valhalla, NY 10595.

Received for publication 16 March 1992 and in revised form 10 August 1992.

J. Clin. Invest.

(C) The American Society for Clinical Investigation, Inc.

0021-9738/93/02/0684/09 \$2.00

Volume 91, February 1993, 684-692 cause of the role of HLA class I antigens in cell proliferation (2-4), interaction of target cells with cytotoxic $T$ cells (for review see reference 5 ), and susceptibility of malignant cells to natural killer $(\mathrm{NK})^{1}$ cell-mediated lysis (for review see reference 6). Besides contributing to the characterization of the machinery regulating HLA class I antigen synthesis and expression, analysis of the molecular mechanisms underlying reduction or loss of HLA class I antigen expression by melanoma cells provides the necessary background to correct these abnormalities. This information may eventually be used to develop therapeutic approaches to melanoma, if the association between poor prognosis and reduction or lack of HLA class I antigen expression in melanoma lesions (7) reflects their role in the clinical course of the disease.

In a recent study we have shown that melanoma cells FO-1 do not express HLA class I antigens because of a gross deletion of the $5^{\prime}$ region and a portion of the coding sequence of the $B_{2} m$ gene that prevents its transcription (8). In the present study, we have characterized the molecular defect that accounts for the lack of HLA class I antigen expression by melanoma cells SKMEL-33.

\section{Methods}

Patient. Patient AZ was a 74-yr-old white male who had a lentigo maligna melanoma excised from the skin of his right scapula in 1972. Two years later, in January 1974, a mass appeared in the left axilla. The mass was excised and revealed metastatic melanoma involving regional lymph nodes. A large $(5 \times 4 \times 4 \mathrm{~cm})$, firm mass reappeared at the apex of the left axilla in June 1974. The patient underwent a deep axillary lymph node dissection. Pathological examination showed metastatic melanoma within lymph nodes invading the surrounding subcutaneous tissue, fat, pectoralis minor muscle, brachial nerve plexus, and brachial vein. The melanoma cell line SK-MEL-33 was established from this lesion. The patient remained free of any recurrent melanoma for $\geq 10 \mathrm{yr}$. He was last seen for follow-up in 1983 when he was $85 \mathrm{yr}$ old. Clinical staging at that time demonstrated no evidence of recurrent melanoma on physical examination, chest $\mathrm{x}$ ray, and liver function tests.

Cell lines, tumor specimen, and $\beta_{2}$-microglobulin $\left(\beta_{2}-\mu\right)$. The melanoma cell line SK-MEL-33 was cultured in RPMI 1640 medium (Gibco Laboratories, Grand Island, NY) supplemented with 10\% FCS, $2 \mathrm{mM}$ L-glutamine, and $1 \%$ nonessential amino acids. The melanoma cell lines FO-1, Colo 38 and $3 \mathrm{~S} 5$ and the B lymphoblastoid cell line MANN were grown in RPMI 1640 medium supplemented with $10 \%$ Serum Plus (Hazelton Biologics, Inc., Lenexa, KS) and $2 \mathrm{mM}$ L-glutamine. Cells were harvested by vigorous pipetting with PBS supplemented with $1 \mathrm{mM}$ EDTA.

1. Abbreviations used in this paper: $\beta_{2}-\mu, \beta_{2}$-microglobulin; ICAM-1, intercellular adhesion molecule-1; NK, natural killer. 
The formalin-fixed and paraffin-embedded specimen of the human malignant melanoma lesion (Clark's level IV), from which the cell line SK-MEL-33 was originally established, was retrieved from the files of the Department of Pathology, Memorial Sloan-Kettering Cancer Center, New York. The tumor had been fixed in $10 \%$ formalin (formaldehyde $4 \% \mathrm{vol} / \mathrm{wt}$, methyl alcohol $1 \% \mathrm{vol} / \mathrm{wt}$, buffered with phosphate buffer) (Mallinckrodt Chemical Works, NY) for $24 \mathrm{~h}$ before embedding into paraffin. One section was cut for standard hematoxylin and eosin staining and three adjacent $20-\mu \mathrm{m}$ thick sections containing only tumor were cut for DNA isolation. Lesional portions of the two unstained sections were scraped with a stainless steel spatula into a $1.5 \mathrm{ml}$ Eppendorf tube.

$\beta_{2}-\mu$ was purified from urine as described (9).

$m A b$ and conventional antisera. The mAb W6/32 to a monomorphic determinant expressed on $\beta_{2}-\mu$-associated HLA class I heavy chains (10); the mAb TP25.99 to a determinant expressed on both $\beta_{2}-\mu$-associated and $\beta_{2}-\mu$-free HLA class I heavy chains (8); the antihuman $\beta_{2}-\mu$ mAb BBM-1 (11), L368 (12), and NAMB-1 (13); the anti-HLA-DR, DQ, DP mAb Q5/13 (14); and the antiintercellular adhesion molecule-1 (ICAM-1) mAb CL207.14 (15) were developed and characterized as described. mAbs were purified from ascitic fluid by sequential precipitation with caprylic acid and ammonium sulphate (16). mAbs were labeled with ${ }^{125}$ I using the iodogen method (17). The immunoreactive fraction of the radiolabeled antibodies was at least $50 \%$ as determined by the method of Lindmo et al. (18).

The rabbit antiserum R5996-4 reacting with denatured HLA class I heavy chain and the rabbit anti-human $\beta_{2^{-}} \mu$ antiserum DP-213456 were prepared by following the methodology described by Nakamuro et al. (19) and by Poulik et al. (20), respectively. Anti-human $\beta_{2}-\mu$ antibodies were purified from rabbit antiserum DP-213456 by affinity chromatography on purified $\beta_{2}-\mu$ coupled to AFFI-GEL 10 (Bio-Rad Laboratories, Richmond, CA) (1 mg/ml of gel). Purified goat anti-rabbit Ig antibodies and rabbit anti-mouse Ig antibodies were purchased from Jackson ImmunoResearch Laboratories, Inc. (Avondale, PA).

$c D N A$ probes, $B_{2} m$ gene, and oligonucleotides. The cDNA probes for human $\beta_{2}-\mu$ (21) and for HLA-B7 antigen (22) were isolated by digestion of plasmids with restriction endonuclease Pstl. The inserts were electrophoresed and excised from low melting agarose gel. Human $\mathrm{B}_{2} \mathrm{~m}$ clone $\mathrm{pb} 2 \mathrm{~m} 13$ in the vector $\mathrm{pEMBL} 9$ (23) was purified on a $\mathrm{CsCl}$ gradient and digested either with $\mathrm{Xbal}$ alone or with the combination of HindIII and XbaI or of EcoRI and SmaI. An upstream 5' fragment (referred to as probe $A$ ), the first exon and much of its flanking sequences (referred to as probe $B$ ), the second and third exons and their flanking sequences (referred to as probe $C$ ), and the fourth exon and its flanking sequences (referred to as probe $D$ ) were separated by electrophoresis on a low melting point agarose gel as described (8). cDNA probes were labeled with $\left[\alpha-{ }^{32} \mathrm{P}\right] \mathrm{dCTP}(3,000 \mathrm{Ci} / \mathrm{mmol}$; Amersham Corp., Arlington Heights, IL) by random priming (24) to a specific activity of $10^{8} \mathrm{cpm} / \mu \mathrm{g}$. Oligonucleotides were end labeled with $\left[\gamma-{ }^{32} \mathrm{P}\right] \mathrm{ATP}(5,000 \mathrm{Ci} / \mathrm{mmol})$ in the presence of $\mathrm{T} 4$ polynucleotide kinase (25).

Oligonucleotides specific for the $\mathrm{B}_{2} \mathrm{~m}$ gene were synthesized on a DNA synthesizer (BioSearch, MilliGen/Biosearch, A Div. of Millipore, Burlington, MA). A 23-nucleotide oligomer (5' TAGAAAGACCAGTCCTTGCTGAA $3^{\prime}$ ) and a 21-nucleotide oligomer (5' TGTATAAGCATATCAATATTA $3^{\prime}$ ) complementary to the codon 56-63 and position $467-486$ in the $3^{\prime}$ untranslated region of human $\beta_{2^{-}} \mu$ mRNA, respectively, were used as primers for RNA sequencing. The nucleotide oligomers ( 5' GTGGAGCATTCAGACTTGTC 3' referred to as primer 1 and $5^{\prime}$ GCAGTGCCACTAATCTGATC 3 ' referred to as primer 2), which define a region of $300 \mathrm{bp}$, including codons 49-95 in the second exon of the $\mathrm{B}_{2} \mathrm{~m}$ gene, were used as primers for PCR. One oligomer ( 5' GCATACTCATTTTTTCAGTG 3') complementary to codon 72-79 in exon 2 of wild-type $B_{2}$ m gene with a cytosine deletion at the region complementary to codon 76 , referred to as probe II, and the other one ( 5 ' TAAGGCCACGGAGCGAGACAT 3') complemen- tary to codon 1-7 in exon 1 of wild-type $B_{2} m$ gene, referred to as probe I, were used for DNA hybridization.

Chemicals and cytokines. Actinomycin D was purchased from Sigma Chemical Co., (St. Louis, MO). Recombinant human IFN- $\gamma$ was obtained from Hoffman-LaRoche, Inc. (Nutley, NJ).

Serological assays. The direct binding assay was performed as described (18) in 96-well microtiter plates (Becton Dickinson Co., Oxnard, CA $)$. Briefly, cells $\left(1 \times 10^{5}\right)$ were incubated with ${ }^{125}$ I-labeled $\mathrm{mAb}\left(2 \times 10^{5} \mathrm{cpm}\right.$ per well $)$ at $4^{\circ} \mathrm{C}$ for $2 \mathrm{~h}$. Then cells were washed five times with PBS and cell bound radioactivity was measured in a gamma counter (LKB-1261; LKB-Wallac, Turku, Finland). Results are expressed as bound cpm per $1 \times 10^{5}$ cells.

Radiolabeling of cells, indirect immunoprecipitation, and SDS $P A G E$. These procedures were performed as described elsewhere (8). Cells were labeled with ${ }^{125} \mathrm{I}$ (Amersham Corp.) using the lactoperoxidase method (26) or with [ $\left.{ }^{35} \mathrm{~S}\right]$ methionine (Amersham Corp.). Then cells were solubilized by incubation for $30 \mathrm{~min}$ at $4^{\circ} \mathrm{C}$ in lysis buffer containing $1 \%$ Nonidet $\mathrm{P}-40,10 \mathrm{mM}$ Tris- $\mathrm{HCl}, \mathrm{pH} 8.2,0.5 \mathrm{M} \mathrm{NaCl}, 1$ $\mathrm{mM}$ EDTA, $1 \mathrm{mg} / \mathrm{ml} \mathrm{BSA}$, and $1 \mathrm{mM}$ PMSF and incubated for $12 \mathrm{~h}$ at $4^{\circ} \mathrm{C}$ with antibodies bound to protein A Sepharose (Pharmacia Inc., Piscataway, NJ). One-dimensional SDS-PAGE analysis was performed under reducing conditions in slab gels containing $12.5 \%$ acrylamide and using the buffer system described by Laemmli (27). Gels containing ${ }^{125}$ I-labeled samples were processed for autoradiography using Kodak XAR-5 film (Eastman Kodak Co., Rochester, NY). Gels containing $\left[{ }^{35} \mathrm{~S}\right]$ methionine-labeled samples were processed for fluorography as described (28).

Preparation of total $m R N A$ and poly $A^{+} R N A$. Total RNA was isolated from cells using the method described by Geliebter et al. (29). Poly(A)-containing RNA was purified by chromatography on oligo(dT) cellulose (Boehringer Mannheim Corp., Indianapolis, IN).

Preparation of DNA from paraffin tissue sections. Tissue sections were incubated in xylene to dissolve the paraffin. The tissue was then pelleted by centrifugation at $12,000 \mathrm{~g}$ for $5 \mathrm{~min}(30,31)$. The supernatant was discarded and after two additional incubations with xylene the pellet was washed sequentially with $100 \%$ and $70 \%$ ethanol. The pellet was resuspended in $100 \mu \mathrm{l}$ of a digestion buffer $(0.2 \mathrm{M}$ Tris- $\mathrm{HCl}, \mathrm{pH} 8$; $10 \mathrm{mM}$ EDTA, $1 \%$ SDS) to which Proteinase $\mathrm{K}$ stored at $-20^{\circ} \mathrm{C}$ was added to a final concentration of $0.5 \mathrm{mg} / \mathrm{ml}$. At the end of a 48-h incubation at $55^{\circ} \mathrm{C}$, more SDS and freshly thawed Proteinase $\mathrm{K}$ were added to the reaction mixture to a final concentration of $2 \%$ and 1 $\mathrm{mg} / \mathrm{ml}$, respectively. Incubation was continued for an additional $25 \mathrm{~h}$ at $55^{\circ} \mathrm{C}$. The sample was then heated to $95^{\circ} \mathrm{C}$ for $6 \mathrm{~min}$ to inactivate Proteinase $\mathrm{K}$ and was extracted twice with phenol-chloroform. Finally, DNA was precipitated in $0.3 \mathrm{M} \mathrm{NaCl}$ and $100 \%$ ethanol at $-70^{\circ} \mathrm{C}$ for $12 \mathrm{~h}$ and pelleted by centrifugation at $12,000 \mathrm{~g}$ for $30 \mathrm{~min}$. The pellet was washed twice with $70 \%$ ethanol and resuspended in 100 $\mu \mathrm{l}$ of filtered and autoclaved water.

RNA hybridization analysis. Total RNA was size fractionated in a $1 \%$ agarose gel containing $2.2 \mathrm{M}$ formaldehyde, transferred to a nitrocellulose membrane, and hybridized with ${ }^{32} \mathrm{P}$-labeled probes as described (8).

DNA hybridization analysis. Genomic DNA was extracted essentially as described by Perbal (32). DNA was digested with restriction endonucleases, size fractionated, transferred to nitrocellulose membrane, and hybridized as described previously $(8)$. When ${ }^{32} \mathrm{P}$-labeled specific oligonucleotides for the $\mathrm{B}_{2} \mathrm{~m}$ gene were used as probes, the hybridization was performed at a temperature $5^{\circ} \mathrm{C}$ below the calculated melting temperature as described (33).

$R N A$ sequencing. $\beta_{2}-\mu$ mRNA was sequenced by following the methodology described by Geliebter et al. (25). Briefly, ${ }^{32} \mathrm{P}$-labeled oligonucleotide primers ( $10 \mathrm{ng})$ and poly $\mathrm{A}^{+} \mathrm{RNA}(20 \mu \mathrm{g})$ were heated to $80^{\circ} \mathrm{C}$ for $3 \mathrm{~min}$ in $15 \mu \mathrm{l}$ of annealing buffer $(250 \mathrm{mM} \mathrm{KCl}, 10 \mathrm{mM}$ Tris- $\mathrm{HCl}, \mathrm{pH} 8.3,1 \mathrm{mM}$ EDTA) and incubated for $60 \mathrm{~min}$ at $60^{\circ} \mathrm{C}$ or at $45^{\circ} \mathrm{C}$. The dideoxynucleotides diluted with $\mathrm{dH}_{2} \mathrm{O}$ in different ratio and $3.3 \mu$ l of reverse transcriptase diluted in extension buffer $(24 \mathrm{mM}$ Tris- $\mathrm{HCl}, \mathrm{pH} 8.3,10 \mathrm{mM} \mathrm{MgCl} 2,8 \mathrm{mM}$ dithiothreitol, $0.2 \mathrm{mM} \mathrm{dATP}$, 
$0.2 \mathrm{mM}$ dCTP, $0.2 \mathrm{mM}$ dTTP, $0.2 \mathrm{mM}$ dGTP) were added into RNA primer-annealing solution, mixed, and incubated for $60 \mathrm{~min}$ at $50^{\circ} \mathrm{C}$. Reactions were terminated by adding $2 \mu$ lof loading buffer ( $100 \%$ formamide, $0.3 \%$ xylene cyanol F, $0.3 \%$ bromophenol blue). Samples were electrophoresed in $6 \%$ polyacrylamide, $8 \mathrm{M}$ urea gel at $17-18 \mathrm{~V}$. After electrophoresis, gels were dried and exposed to Kodak XAR-5 film (Eastman Kodak Co.) for $72 \mathrm{~h}$ at $-70^{\circ} \mathrm{C}$. Nucleotide sequences were translated into amino acid sequences by using the software microgenie (Version 7.0, Beckman Instruments, Inc., Fullerton, CA).

In vitro amplification of genomic DNA. Extracted DNA was used as a template for amplification using the Thermus aquaticus ( TaqI) heatstable DNA polymerase as described (34). Amplifications were performed in siliconized tubes (Biomedica, Rutherford, $\mathrm{NJ}$ ) in a $50-\mu \mathrm{l}$ solution containing genomic DNA template, $50 \mathrm{mM} \mathrm{KCl}, 10 \mathrm{mM}$ Tris, $\mathrm{pH} 8.4,2.5 \mathrm{mM} \mathrm{MgCl}_{2}, 300 \mathrm{ng}$ of primer 1 and primer $2,200 \mu \mathrm{M}$ of each deoxyribonucleotide triphosphate (dATP, dCTP, dTTP, and dGTP), $100 \mu \mathrm{g}$ of gelatin $/ \mathrm{ml}$, and $3 \mathrm{U}$ of Taql DNA polymerase (Perkin-Elmer Cetus Instruments, Norwalk, CT). Samples were overlaid with $50 \mu \mathrm{l}$ of mineral oil to prevent condensation and were subjected to 35 cycles of amplification. The cycling reaction was performed in a programmable heat block (DNA Thermal Cycler; Perkin-Elmer Cetus Instruments) set to heat samples to $94^{\circ} \mathrm{C}$ for $1 \mathrm{~min}$, cool them to $50^{\circ} \mathrm{C}$ over $1 \mathrm{~min}$, and heat them to $73^{\circ} \mathrm{C}$ for $1 \mathrm{~min}$. In the first cycle DNA was denatured at $94^{\circ} \mathrm{C}$ for $5 \mathrm{~min}$. Amplified DNA was analyzed by nondenaturing agarose gel electrophoresis. $5 \mu \mathrm{l}$ of the amplification reaction was electrophoresed on a $1.5 \%$ Tris-Borate-EDTA agarose gel (FMC Corp., Rockland, ME) in the presence of ethidium bromide.

Cloning and sequencing of $P C R$ products. $\mathrm{B}_{2} \mathrm{~m}$ PCR products were ligated into plasmid vector PCR (Invitrogen, San Diego, CA) and used to transform competent bacteria (Escherichia coli $\mathrm{INV} \alpha \mathrm{F}^{\prime}$ ). Single colonies of transformed bacteria were selected in medium containing kanamycin $(50 \mu \mathrm{g} / \mathrm{ml})$ and grown to mass culture. Amplified plasmid was extracted according to established protocols (35) and used in direct DNA sequencing reactions using the chain-termination technique (36) with a modified T7 DNA polymerase (37), (Sequenase 2.0; United States Biochemical Corp., Cleveland, $\mathrm{OH})$. Plasmid DNA $(2.5 \mu \mathrm{g})$ was incubated with $10 \mathrm{ng}$ of M13(-)20 Primer-(5'-GTAAAACGACGGCCAGT-3') (Stratagene, Inc., La Jolla, CA) in 0.25 N NaOH at $20^{\circ} \mathrm{C}$ for $5 \mathrm{~min}$. Denatured plasmid and annealed primer mixture were then precipitated with $5 \mathrm{M}$ ammonium acetate, $\mathrm{pH} 4.6$, and ethanol and were centrifuged at $15,000 \mathrm{~g}$ for $15 \mathrm{~min}$. Pellets were washed with $70 \%$ ethanol, recentrifuged, dried, and resuspended in $8 \mu \mathrm{l}$ of water. The annealed primer/template mixture was supplemented with $1 \mu \mathrm{l} 0.1 \mathrm{M}$ DDT, $1 \mu \mathrm{l} 10 \mathrm{mU}\left[\alpha_{-}{ }^{35} \mathrm{~S}\right] \mathrm{dATP}(1,000 \mathrm{Ci} / \mathrm{mmol}$; New England Nuclear, Boston, MA), $2 \mu$ l dilute labeling mixture (1:5), and $3 \mathrm{U}$ of Sequenase 2.0 (United States Biochemical Corp.). The reaction mixture was mixed, incubated for $2 \mathrm{~min}$ at room temperature, and aliquoted into four tubes containing $2.5 \mu \mathrm{l}$ of the respective deoxy/dideoxy termination mixture ( $80 \mu \mathrm{M}$ dATP, $80 \mu \mathrm{M}$ dCTP, $80 \mu \mathrm{M}$ dGTP, $80 \mu \mathrm{M}$ dTTP, and $8 \mu \mathrm{M}$ of the respective dideoxy nucleotide triphosphate). After a $10-\mathrm{min}$ incubation at $37^{\circ} \mathrm{C}, 4 \mu \mathrm{l}$ of stop buffer $(95 \%$ formamide, $20 \mathrm{mM}$ EDTA, $0.05 \%$ bromophenol blue, and $0.05 \% \mathrm{xy}-$ lene cyanol) was added to each tube. Tubes were then heated to $94^{\circ} \mathrm{C}$ for $2 \mathrm{~min}$. The reaction mixture was loaded on an $8 \%$ polyacrylamide$8 \mathrm{M}$ urea gel and run for $4 \mathrm{~h}$ at constant wattage.

Transfection of SK-MEL-33 melanoma cells with a wild-type human $B_{2} m$ gene. The procedure we used previously (8) was followed with minor modifications. Briefly, cells $\left(1 \times 10^{7}\right)$, linearized human $\mathrm{B}_{2} \mathrm{~m}$ DNA fragment $(100 \mu \mathrm{g})$, and EcoRI-digested pSV2neo $(5 \mu \mathrm{g})$ were suspended in $1 \mathrm{ml}$ of cold PBS. An electroporation power supply (Bethesda Research Laboratories, Gaithersburg, MD) applied an electric pulse of $1 \mathrm{kV}$ and $330 \mu \mathrm{F}$ to the chamber containing cells. Cells were then recovered in RPMI 1640 medium supplemented with $10 \%$ FCS, seeded in eight 100 -mm tissue culture dishes, and incubated at $37^{\circ} \mathrm{C}$ in $5 \% \mathrm{CO}_{2}$ for $7 \mathrm{~d}$. On day $8, \mathrm{G} 418$-sulfate was added to the medium at the final concentration of $2 \mathrm{mg} / \mathrm{ml}$. The concentration of G418-sulfate was reduced to $0.4 \mathrm{mg} / \mathrm{ml}$ after $3 \mathrm{~d}$ of incubation and maintained at this level for an additional $10 \mathrm{~d}$. Cell colonies were de- tached with HBSS containing trypsin-EDTA, picked up with a plastic ring, and expanded.

\section{Results}

Lack of HLA class I antigen expression by SK-MEL-33 melanoma cells. SK-MEL-33 cells did not react in a binding assay with ${ }^{125} \mathrm{I}$-mAb W6/32 recognizing a monomorphic determinant expressed on $\beta_{2}-\mu$-associated HLA class I heavy chains, with ${ }^{125} \mathrm{I}-\mathrm{mAb}$ TP25.99 to a determinant expressed on $\beta_{2}-\mu-$ associated and $\beta_{2}-\mu$-free HLA class I heavy chains, and with ${ }^{125}$ I-labeled anti- $\beta_{2}-\mu$ mAb NAMB-1 (Fig. 1). No reactivity with these $\mathrm{mAbs}$ was detected also after incubation of cells with IFN- $\gamma(1,000 \mathrm{U} / \mathrm{ml})$ for $3 \mathrm{~d}$ before testing (Fig. 1). Furthermore, no component was immunoprecipitated from control and IFN- $\gamma$-treated ${ }^{125}$ I-labeled SK-MEL-33 cells by anti-HLA Class I mAb W6/32 and TP25.99 and by anti- $\beta_{2}-\mu$ mAb NAMB-1. Neither control nor IFN- $\gamma$-treated SK-MEL-33 cells reacted with ${ }^{125} \mathrm{I}$-labeled anti-HLA-DR, DQ, DP mAb Q5/13 (Fig. 1). SK-MEL-33 cells were sensitive to the modulating activity of IFN- $\gamma$, since IFN- $\gamma$-treated cells displayed a marked increase in the reactivity with anti-ICAM-1 mAb CL207.14 (Fig. 1).

Intracellular expression of HLA class I heavy chains and truncated $\beta_{2}-\mu$ by $S K-M E L-33$ melanoma cells. To determine whether the heavy chain of HLA class I antigens and $\beta_{2}-\mu$ are synthesized by SK-MEL-33 cells, an NP40 extract of $\left[{ }^{35} \mathrm{~S}\right]-$ methionine-labeled cells was immunoprecipitated with several anti-HLA class I mAbs, and analyzed by SDS-PAGE. No component was detected in the immunoprecipitate with anti-HLA class I mAb W6/32 and with anti- $\beta_{2}-\mu$ mAbs BBM-1, L368,

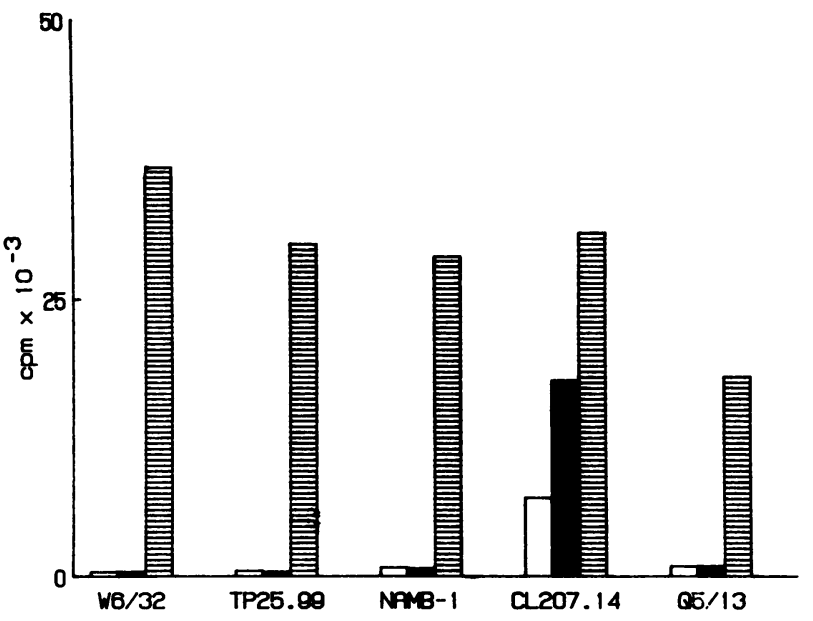

Figure 1. Lack of reactivity of control and IFN- $\gamma$-treated cultured melanoma cells SK-MEL-33 with anti-HLA class I mAbs. SK-MEL33 cells were incubated at $37^{\circ} \mathrm{C}$ for $72 \mathrm{~h}$ with IFN- $\gamma$ (final concentration $1,000 \mathrm{U} / \mathrm{ml})(\square)$. Control cells $(\square)$ were incubated under the same experimental conditions, but without cytokine. Cells were then harvested, washed twice with HBSS, and tested with ${ }^{125} \mathrm{I}-\mathrm{mAb}$ W6/32 to a determinant expressed on $\beta_{2}-\mu$-associated HLA class I heavy chain, ${ }^{125} \mathrm{I}-\mathrm{mAb}$ TP25.99 to a determinant expressed on $\beta_{2}-\mu$-associated and $\beta_{2}-\mu$-free HLA class I heavy chain, ${ }^{125} \mathrm{I}$-anti- $\beta_{2}-\mu \mathrm{mAb}$ NAMB-1 and ${ }^{125} \mathrm{I}$-anti-HLA-DR,DQ,DP $\mathrm{mAb}$ Q5/13 in a binding assay. ${ }^{125}$ I-anti-ICAM-1 mAb CL207.14 was used to monitor the susceptibility of SK-MEL-33 cells to modulation by IFN- $\gamma$. The reactivity of radiolabeled anti-HLA mAb preparations was monitored by testing with cultured melanoma cells Colo $38(\mathrm{\theta})$ in a binding assay. 


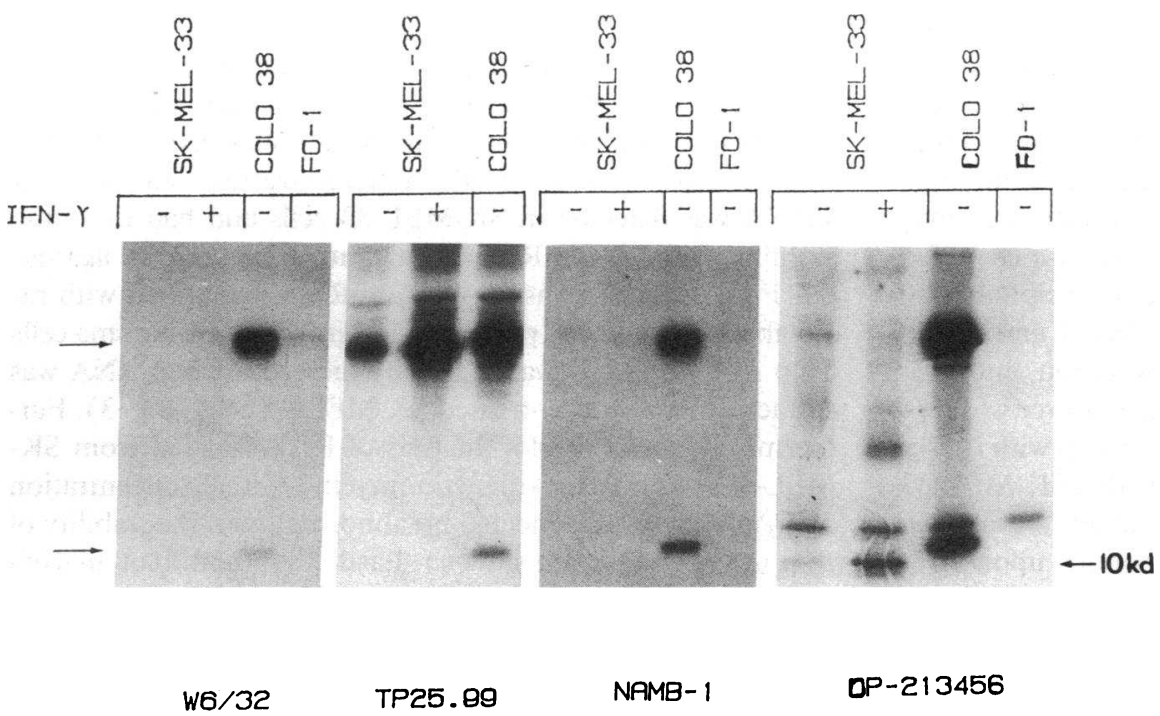

Figure 2. SDS-PAGE analysis of antigens immunoprecipitated from control and IFN- $\gamma$-treated cultured melanoma cells SK-MEL-33 by anti-HLA class I monoclonal and polyclonal xenoantibodies. After a 72-h incubation at $37^{\circ} \mathrm{C}$ in medium supplemented with IFN- $\gamma$ (final concentration $1,000 \mathrm{U} / \mathrm{ml}$ ), SK-MEL-33 cells were starved for $1 \mathrm{~h}$ in methionine-free medium and intrinsically radiolabeled with $\left[{ }^{35} \mathrm{~S}\right]-$ methionine. Control SK-MEL-33 cells were cultured and radiolabeled under the same experimental conditions but were not exposed to IFN- $\gamma$. At the end of the incubation, cells were harvested, washed three times with HBSS, and solubilized with $1 \%$ NP40. Antigens were immunoprecipitated with $\mathrm{mAb}$ W6/32 to a determinant expressed on $\beta_{2}-\mu$-associated HLA class $I$ heavy chains, with mAb TP25.99 to a determinant expressed on $\beta_{2}-\mu$-free and $\beta_{2}$ $\mu$-associated HLA class I heavy chains, with anti- $\beta_{2}-\mu$ mAb NAMB-1, and with

anti- $\beta_{2}-\mu$ polyclonal antibodies isolated from rabbit anti- $\beta_{2}-\mu$ serum DP-213456. Antigens were then eluted from the immunoabsorbent and analyzed by SDS-PAGE in the presence of $2 \% \beta$-mercaptoethanol. Gels were then processed for fluorography (27). Arrows indicate the position of HLA class I heavy chain and $\beta_{2}-\mu$ and of the $10-\mathrm{kD}$ component precipitated from SK-MEL-33 cells. Cultured melanoma cells Colo 38 , which express HLA class I antigens and cultured melanoma cells, FO-1, which synthesize HLA class I heavy chains, but do not synthesize $\beta_{2}-\mu(8)$, were used as controls to monitor the activity of the antibody preparations and the specificity of the immunoprecipitation patterns.

and NAMB-1. Representative results are shown in Fig. 2. In contrast, HLA class I heavy chains were detected in the immunoprecipitate with the mAb TP25.99 and with the xeno-antiserum R5996-4. The latter two reagents react with $\beta_{2}-\mu-$ free
HLA class I heavy chains. Furthermore, a component with the apparent molecular mass of $10 \mathrm{kD}$ was detected in the immunoprecipitate with anti-human $\beta_{2}-\mu$ antibodies purified from rabbit anti-human $\beta_{2}-\mu$ serum DP-213456 by affinity chromatogra-
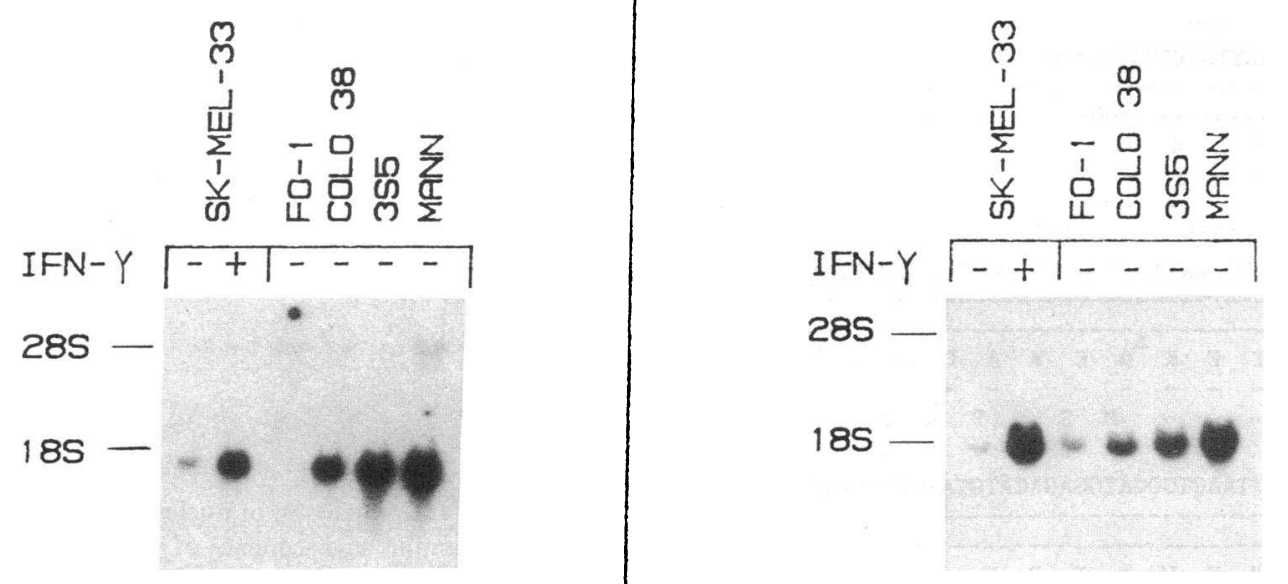

Figure 3. Northern blot analysis of HLA class I heavy chain and $\beta_{2}-\mu$ mRNA in cultured melanoma cells SKMEL-33. SK-MEL-33 cells were incubated at $37^{\circ} \mathrm{C}$ for $72 \mathrm{~h}$ with IFN- $\gamma$ (final concentration $1,000 \mathrm{U} / \mathrm{ml}$ ). Control cells were incubated under the same experimental conditions, but without cytokine. At the end of the incubation, cells were harvested and total cytoplasmic RNA was extracted and hybridized with ${ }^{32} \mathrm{P}$-labeled $0.5-\mathrm{kb}$ human $\beta_{2}-\mu$ cDNA probe $(A)$ and with ${ }^{32} \mathrm{P}$-labeled 1.4-kb HLA-B7 cDNA probe $(B)$. Controls analyzed for comparison purposes included RNA isolated from cultured melanoma cells FO-1, which transcribe the HLA class I heavy chain genes, but do not transcribe the $\mathrm{B}_{2} \mathrm{~m}$ genes, from cultured melanoma cells Colo 38 and 3S5 and from cultured B lymphoid cells MANN, all of which transcribe the HLA class I heavy chain and $B_{2} m$ genes. 
phy on $\beta_{2}-\mu$. This component, which has a smaller size than that immunoprecipitated from $\left[{ }^{35} \mathrm{~S}\right.$ ] methionine-labeled cultured melanoma cells Colo 38 , is not associated with HLA class I heavy chains. The immunoprecipitation pattern was specific, since purified rabbit anti- $\beta_{2}-\mu$ antibodies did not immunoprecipitate the $10-\mathrm{kD}$ component and $12 \mathrm{kD} \beta_{2}-\mu$ from cultured melanoma cells FO-1, which do not synthesize $\beta_{2}-\mu(8)$. The intensity of HLA class I heavy chains immunoprecipitated by mAb TP25.99 and by rabbit antiserum R5996-4 and of the $10-\mathrm{kD}$ component immunoprecipitated by rabbit anti- $\beta_{2}-\mu$ xenoantibodies was increased when the antigen source was represented by SK-MEL-33 melanoma cells incubated with IFN- $\gamma$ $(1,000 \mathrm{U} / \mathrm{ml})$ for $72 \mathrm{~h}$. These results indicate that SK-MEL-33 cells synthesize HLA class I heavy chains and abnormal $\beta_{2}-\mu$; the latter had an increased electrophoretic mobility upon SDSPAGE and lacked the ability to associate with HLA class I heavy chains.
Northern and Southern blot analysis of $\beta_{2}-\mu$ in SK-MEL-33 melanoma cells. To investigate the mechanism(s) underlying the synthesis of an abnormal $\beta_{2}-\mu$, which does not associate with HLA class I heavy chains, the steady state level of mRNA for $\beta_{2}-\mu$ was evaluated by RNA hybridization analysis. $\beta_{2}-\mu$ mRNA was detected in SK-MEL-33 cells and had the same mobility as the $\beta_{2}-\mu$ mRNA from control cells in a $1 \%$ agarose gel (Fig. 3). The intensity of $\beta_{2}-\mu$ mRNA hybridized with radiolabeled $\beta_{2}-\mu$ cDNA probe was lower than in melanoma cells Colo 38 and 3S5; it was markedly increased when RNA was extracted from IFN- $\gamma$-treated SK-MEL-33 cells (Fig. 3). Furthermore, Northern blot analysis of RNA isolated from SKMEL-33 cells treated with actinomycin D ( final concentration $5 \mu \mathrm{g} / \mathrm{ml}$ ) for $\leq 2 \mathrm{~h}$ detected no abnormality in the stability of $\beta_{2}-\mu$ mRNA (data not shown). Lastly, Southern blot analysis using four DNA fragments isolated from $B_{2} m$ gene clone $\operatorname{pb} 2 \mathrm{~m} 13(8,23)$ as probes detected no difference in the restric-

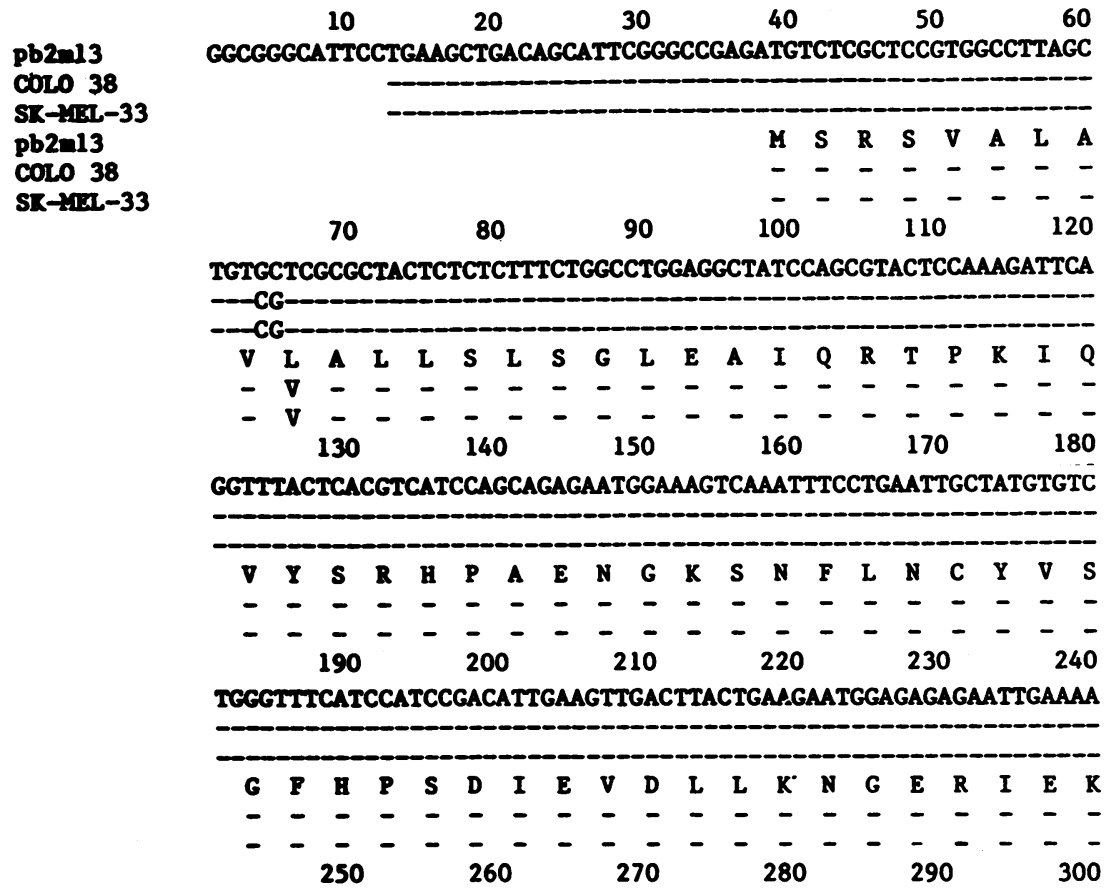

AGTGGAGCATTCAGACTTGTCTTTCAGCAGGACTGGTCTTTCTATCTCTTGTACTACAC

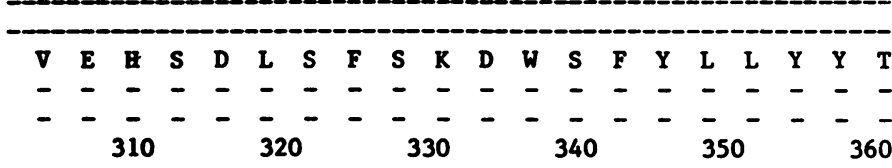

TGAATCACCCCCACTGMAAAGATGAGTATGCCTGCCGTGTGACCATGTGACTTTGTC

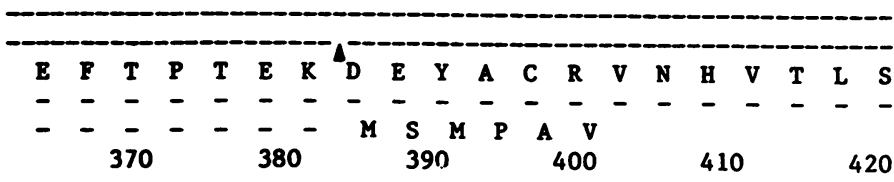

ACAGCCCAAGATAGTTAAGTGGGATCGAGACATGTAAGCAGCATCATGGAGGTTTGAAGA

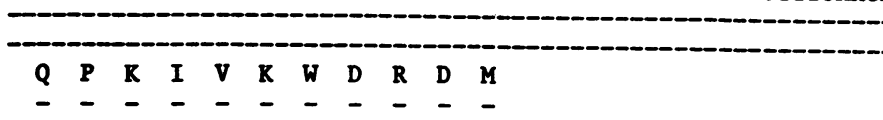

$430 \quad 440$

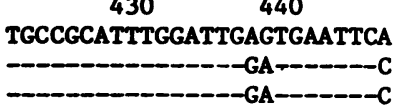

Figure 4. Comparison of nucleotide and deduced amino acid sequence of $\beta_{2}-\mu$ mRNA from SK-MEL-33 melanoma cells with that of $\beta_{2}-\mu$ mRNA from Colo 38 melanoma cells and with the published sequence of $\mathrm{pb} 2 \mathrm{~m} 13$. Dashes indicate sequence identity. The arrow indicates the base deletion detected in SKMEL-33 cells. 
tion pattern of the genomic DNA between SK-MEL-33 cells and melanoma cells Colo 38 (data not shown).

Reading frameshift mutation in $\beta_{2}-\mu$ mRNA of SK-MEL-33 melanoma cells. To determine the molecular basis for the synthesis of an abnormal $\beta_{2}-\mu$ by SK-MEL-33 cells, the $\beta_{2}-\mu$ mRNA sequence was determined. $\beta_{2}-\mu$ mRNA from Colo 38 melanoma cells, which express HLA class I antigens, was sequenced as a wild-type control. The sequences of the $\beta_{2}-\mu$ mRNA from the two melanoma cell lines displayed a $99.8 \%$ homology between themselves and of at least $98.6 \%$ with the published sequence of pb2m13 (Fig. 4). The SK-MEL-33 and Colo $38 \beta_{2}-\mu$ mRNA sequences differ from that of $\mathrm{pb} 2 \mathrm{~m} 13$, with transition of CG to $\mathrm{GC}$ at positions 64 and 65 , AG to $\mathrm{GA}$ at positions 437 and 438 , and $A$ to $C$ at position 446 . All of these nucleotide substitutions were silent except that occurring at position 65 , which resulted in a switch from valine to leucine at position -11 within the leader peptide. No alteration was detected in the leader sequence and in the initiation codon of SK-MEL-33 $\beta_{2}-\mu$ mRNA. However, the base guanosine was deleted at position 323 (in codon 76) of the sequence of $\beta_{2}-\mu$ mRNA in SK-MEL-33 cells (Fig. 5). To confirm the base deletion in $B_{2} m$ gene of SK-MEL-33 cells, a Southern blot analysis was performed using an oligonucleotide probe complementary to the codon 72-79 sequence of $\beta_{2}-\mu$ mRNA of SK-MEL-33 cells with the deletion of a cytosine at the region complementary to codon 76 ( referred to as probe II). For this analysis an oligonucleotide complementary to the codon 1-7 of wild-type human $\beta_{2}-\mu$ (referred to as probe I) was used as a control. A temperature $5^{\circ} \mathrm{C}$ below the melting temperature was used for

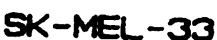

C T G A

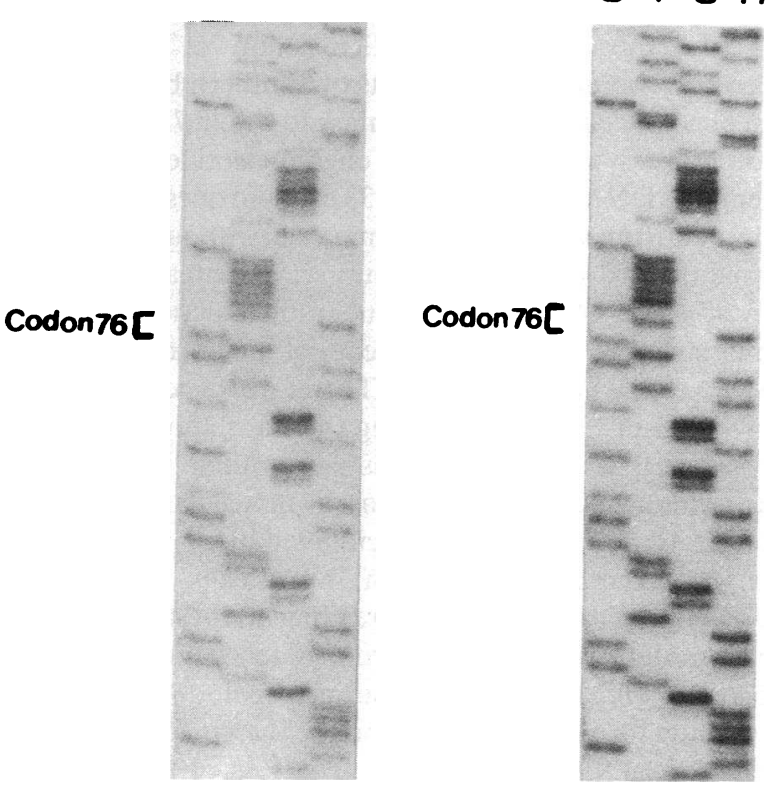

Figure 5. Sequencing gel of $\beta_{2}-\mu$ mRNA in SK-MEL-33 melanoma cells. RNA sequencing was primed with an oligonucleotide complementary to the $\beta_{2}-\mu$ mRNA at position $467-486$ of $3^{\prime}$ untranslated region. The sequence, when read bottom to top, is complementary to the sense strand in $3^{\prime} \rightarrow 5^{\prime}$ orientation. The sequence complementary to codon 76 is indicated. $\beta_{2}-\mu$ mRNA from cultured human melanoma cells Colo 38 was sequenced as a control.

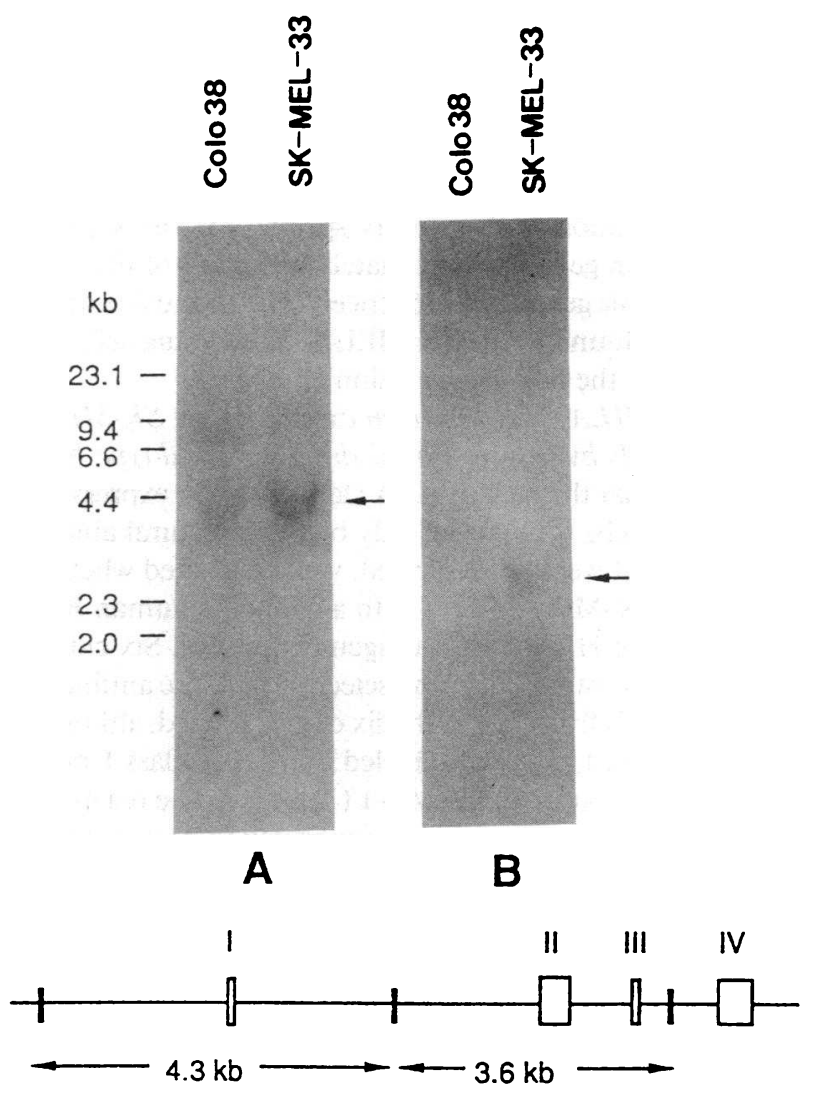

Figure 6. Southern blot analysis with oligonucleotides of $\mathrm{B}_{2} \mathrm{~m}$ gene in cultured melanoma cells SK-MEL-33. DNA $(30 \mu \mathrm{g})$ isolated from cultured melanoma cells SK-MEL-33 (lane 2) was digested overnight at $37^{\circ} \mathrm{C}$ with the restriction enzyme Xbal. Digested DNA was fractionated on a $1 \%$ agarose gel and transferred to nitrocellulose filters. Blots were hybridized with a ${ }^{32} \mathrm{P}$-labeled oligonucleotide probe I complementary to codon 1-7 of wild-type human $\beta_{2}-\mu$ mRNA $(A)$ and with a ${ }^{32} \mathrm{P}$-labeled oligonucleotide probe II with a cytosine deletion at the region complementary to codon $76(B)$. DNA (30 $\mu \mathrm{g}$ ) from cultured melanoma cells Colo 38 (lane 1 ) was run as a control. The marker lane contained $\lambda$ phage DNA digested with HindIII. The bottom shows the map of the $B_{2} m$ gene with restriction enzyme Xbal sites indicated by black blocks. The open blocks indicate the four exons.

hybridization. The ${ }^{32} \mathrm{P}$-oligonucleotide probe II hybridized to a $3.6 \mathrm{~kb}$ Xbal genomic DNA fragment from SK-MEL-33 cells but did not hybridize to that from Colo 38 cells. On the other hand, the ${ }^{32} \mathrm{P}$-oligonucleotide probe I hybridized to a $4.3 \mathrm{~kb}$ Xbal genomic DNA fragment both from Colo 38 cells and from SK-MEL-33 cells (Fig. 6). These results corroborate the sequencing data that guanosine was deleted at position 323 (in codon 76) in $\beta_{2}-\mu$ mRNA of SK-MEL-33 cells.

The guanosine deletion causes a frameshift with a subsequent introduction of a stop codon at a position 54 bases upstream of the normal position of the stop codon in the message (Fig. 4). This results in the translation of a truncated protein that is 18 amino acids shorter than the wild-type $\beta_{2}-\mu$ protein. Furthermore, the changes from codon 76 to codon 81 result in the substitution of the corresponding six amino acids. Of great significance in terms of the overall structure of $\beta_{2}-\mu$, is the replacement with an alanine of a cysteine that is at position 80 in the $\beta_{2}-\mu$ polypeptide. 
Detection of a guanosine deletion in $\beta_{2-\mu}$ in melanoma tissue from which the SK-MEL-33 cell line had originated. To determine whether the base deletion detected in SK-MEL-33 cells was present in the lesion from which the cell line had originated, DNA extracted from the melanoma lesion was used for PCR amplification with primers specific for the second exon of the human gene. Approximately 200 bases of the amplified region of this gene were sequenced. The guanosine deletion in codon 76 found in the SK-MEL-33 melanoma cell line was found also in the melanoma lesion (Fig. 7).

Induction of HLA class I antigen expression on $S K-M E L$ 33 melanoma cells by transfection with human wild-type $B_{2} m$ gene. To prove that the lack of HLA class I antigen expression by SK-MEL-33 cells was caused only by the structural abnormality of $\beta_{2}-\mu$ that we have described, we determined whether transfection of SK-MEL-33 cells with a wild-type human $B_{2} m$ gene could induce HLA class I antigen expression. Six clones were isolated after transfection and selection with the antibiotic G418-sulfate. Cells from five of the six clones reacted, although to a different extent, with ${ }^{125} \mathrm{I}$-labeled anti-HLA class I mAb W6/32 and anti- $\beta_{2}-\mu$ mAb NAMB-1 (Table I). The reactivity is specific since the transfected cells continued to be unreactive with the anti-HLA-DR, DQ, DP mAb Q5/13. Furthermore, neither mAb W6/32 nor mAb NAMB-1 reacted with melanoma cells SK-MEL-33 transfected with the pSV2neo gene alone.

\section{Discussion}

Serological and immunochemical analysis with monoclonal and polyclonal xenoantibodies has shown that cultured melanoma cells SK-MEL-33 do not express HLA class I antigens on their cell surface and do not acquire them after incubation with IFN- $\gamma$. This abnormality reflects the synthesis of a truncated $\beta_{2}-\mu$ that does not associate with HLA class I heavy chains. Since association with $\beta_{2}-\mu$ is required for the transport of HLA class I heavy chains to cell membrane $(38,39)$, HLA class I heavy chains that are synthesized by melanoma cells SK-MEL33 remain in the cytoplasm and are not expressed on the cell surface. This conclusion is supported by the results of immunoprecipitation experiments performed with an extract of intrinsically radiolabeled melanoma cells SK-MEL-33 and antiHLA class I $m A b$ with distinct specificities. HLA class I heavy chains are immunoprecipitated by mAb TP25.99, which recognizes a determinant expressed also on $\beta_{2}-\mu$-free HLA class I

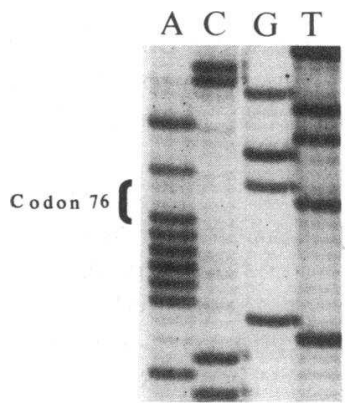

Figure 7. Direct sequence analysis of the region surrounding codon 76 of the $B_{2} m$ gene in the surgically removed melanoma lesion from which the cell line SK-MEL-33 was originated. DNA was extracted from paraffin-embedded lesion, amplified in vitro using PCR. The PCR products were ligated into plasmid vector $\mathrm{pCR}$ and used to transform $E$. coli INV $\alpha \mathrm{F}$. The plasmid amplified from single colonies was extracted and used in direct DNA sequencing reactions using the chain-termination technique. The sequence, when read bottom to top, is the sense strand in $5^{\prime} \rightarrow 3^{\prime}$ orientation. The sequence shown corresponds to the stretch from codons 73 to 79 .
Table I. Reactivity with Anti-HLA Class I MAb of SK-MEL-33 Melanoma Cells Transfected with Human Wild-Type $B_{2} m$ Gene*

\begin{tabular}{lccc}
\hline & \multicolumn{3}{c}{${ }^{125}$ I-labeled mAb } \\
\cline { 2 - 4 } \multicolumn{1}{c}{ Cells } & W6/32 & NAMB-1 & $\mathrm{Q} 5 / 13$ \\
\hline & & $c p m \times 10^{-3}$ \\
$\mathrm{~T}_{3}$-1 $^{\ddagger}$ & $24.2^{* *}$ & 18.7 & 0.2 \\
$\mathrm{~T}_{3}-2$ & 5.2 & 4.7 & 0.1 \\
$\mathrm{~T}_{3}-3$ & 0.2 & 0.6 & 0.2 \\
$\mathrm{~T}_{3}-4$ & 5.3 & 4.6 & 0.8 \\
$\mathrm{~T}_{3}-5$ & 18.0 & 17.7 & 0.2 \\
$\mathrm{~T}_{3}-7$ & 23.2 & 17.8 & 0.1 \\
SK-MEL-33 neo & 0.2 & 1.4 & 0.7 \\
SK-MEL-33" & 0.2 & 0.6 & 0.1 \\
Colo 38' & 21.3 & 15.9 & 9.1 \\
& & & \\
\hline
\end{tabular}

* Cells were tested with ${ }^{125} \mathrm{I}$-mAb W6/32 to a determinant expressed on $\beta_{2}-\mu$-associated HLA class I heavy chains and ${ }^{125} \mathrm{I}$-anti- $\beta_{2}-\mu \mathrm{mAb}$ NAMB-1 in a binding assay. ${ }^{125} \mathrm{I}$-anti-HLA-DR, DQ, DP mAb Q5/13 was used as a specificity control. ${ }^{\ddagger}$ Clones isolated after transfection of SK-MEL-33 cells with linearized human $\mathrm{B}_{2} \mathrm{~m}$ DNA fragment and EcoRI-digested pSV2 neo and selection with the antibiotic G-418 sulfate. ${ }^{8}$ Clone isolated after transfection of SK-MEL-33 cells with EcoRI-digested pSV2 neo and selection with the antibiotic G-418 sulfate. "Untransfected cells. "Cultured melanoma cells Colo 38 were used to monitor the reactivity of radiolabeled anti-HLA mAb preparations in a binding assay. ${ }^{* *} \mathrm{cpm} \times 10^{-3} / 1 \times 10^{5}$ cells.

heavy chains (8), but are not immunoprecipitated by mAb W6/32, which requires the association of the HLA class I heavy chain with $\beta_{2}-\mu$ for the expression of the corresponding determinant (40).

Sequencing of $\beta_{2}-\mu$ mRNA from SK-MEL-33 detected a deletion of guanosine at position 323 in codon 76 . This finding has been corroborated by the results of Southern blot analysis with an oligonucleotide complementary to codon 72-79 of SKMEL-33 cells $\beta_{2}-\mu$ mRNA. This oligonucleotide hybridizes with genomic DNA from SK-MEL-33 cells but does not hybridize with that from Colo 38 melanoma cells without detectable abnormalities in $\beta_{2}-\mu$. The base deletion causes a reading frameshift in $\beta_{2}-\mu$ mRNA with a subsequent introduction of a stop codon in codon 82 ( 54 bases upstream of the normal position of the stop codon) in the message. Therefore, the codons from 82 to 99 are not translated, causing the translation of a truncated protein that is 18 amino acids shorter than the wild-type protein. This accounts for the apparent molecular mass of 10 $\mathrm{kD}$ of the component immunoprecipitated by polyclonal antihuman $\beta_{2}-\mu$ xenoantibodies from intrinsically labeled SKMEL-33 cells. Furthermore, the reading frameshift causes a missense mutation in the codons from 76 to 81 and a change in the corresponding amino acids. The latter include replacement of an alanine for cysteine at position 80 , thereby disrupting an intrachain disulfide bond in $\beta_{2}-\mu$. The loss of this disulfide bond is likely to have dramatic effects on the structure of $\beta_{2}-\mu$ in SK-MEL-33 cells, since $\beta_{2}-\mu$ has been shown to have a $\beta$ sandwich structure composed of two antiparallel $\beta$-pleated sheets joined by a disulfide linkage (41). The lack of this disulfide bond in SK-MEL-33 cells, the introduction of 6 amino acid substitutions, and the loss of 18 amino acids in the carboxy terminus of $\beta_{2}-\mu$ are likely to cause marked changes in the 
conformation and structure of the polypeptide. The latter may account for the lack of association of $\beta_{2}-\mu$ with HLA class I heavy chains and the lack of reactivity with mouse anti-human $\beta_{2}-\mu \mathrm{mAb}$. An alternative, but not exclusive possibility for the lack of reactivity with mouse anti-human $\beta_{2}-\mu \mathrm{mAb}$ may be the loss of the corresponding determinants located on the carboxy terminus of $\beta_{2}-\mu$, since the most significant difference in the sequence of human and mouse $\beta_{2}-\mu$ is located at the carboxy terminus of the molecule (42). Therefore, this moiety is likely to be the most immunogenic when mice are immunized with human $\beta_{2}-\mu$.

Karyotype analysis indicates that SK-MEL-33 cells contain two copies of chromosome 15 (unpublished results) where the $B_{2} \mathrm{~m}$ gene maps (43). No rearrangement of the $B_{2} m$ gene was found by Southern blot analysis of SK-MEL-33 cell DNA with fragments of wild-type $B_{2} m$ gene as probes. Nevertheless, biochemical analysis demonstrated that SK-MEL-33 cells synthesize only a truncated $\beta_{2}-\mu$ polypeptide. Therefore, it is likely that a wild-type allele of $\beta_{2}-\mu$ was deleted or is nonfunctional, since melanoma cells in metastatic lesions are genetically unstable and are characterized by widespread chromosomal alterations, including genetic deletions (44). The mechanisms for loss of a functional $\beta_{2}-\mu$ allele include, $(a)$ hemizygosity, with loss of a wild-type allele and duplication of the mutant $B_{2} \mathrm{~m}$ gene; $(b)$ deletion of the wild-type allele without duplication of the mutant allele; or $(c)$ transcription of only the mutant copy of the $\mathrm{B}_{2} \mathrm{~m}$ gene due to mutations in coding or noncoding regions that are undetectable with the probes we have used. Whatever is the mechanism underlying the lack of translation of a functional $\beta_{2}-\mu$ in SK-MEL-33 cells, abnormal $\beta_{2}-\mu$ is the only defect responsible for lack of HLA class I antigen expression by SK-MEL-33 cells, since their transfection with a wild-type human $B_{2} m$ gene induced their expression.

SK-MEL-33 cells are not the first example of human cells without detectable HLA class I antigen expression because of a $\beta_{2}-\mu$ abnormality. Cultured lymphoblastoid Daudi cells, which are the most extensively characterized human cells without detectable HLA class $I$ antigen expression, transcribe the $B_{2} m$ gene but do not translate $\beta_{2}-\mu$ mRNA $(20,45)$ because of a point mutation in the initiation codon (46). Cultured melanoma cells FO- 1 do not transcribe the $B_{2} m$ gene because of a deletion of the first exon, of the 5'-flanking region, and of a segment of the first intron of the $B_{2} m$ gene (8). A similar defect has been identified in four mouse cell lines derived from the C48 mouse thymoma cell line $\mathrm{R} 1.1$ by chemical or irradiation mutagenesis and subsequent selection with anti-TL antisera and complement (47-49). Interestingly, a similar treatment of cultured human B lymphoblastoid cells has caused the mutations of genes located in the HLA class II region which control the HLA class I antigen presentation pathway $(50,51)$. On the other hand, no abnormalities in the structure of $\beta_{2}-\mu$ polypeptide and/or in mechanisms that regulate transcription or translation of the gene have been induced. SK-MEL-33 cells are the first example of cells with a structurally abnormal $\beta_{2}-\mu$ because of a frameshift mutation due to deletion of a single nucleotide. Furthermore, SK-MEL-33 cells represent the first example in which the same HLA class I molecular abnormality present in the cell line could be detected in the original melanoma lesion from the patient. These findings show that the lesion we have identified in the SK-MEL-33 cell line is not caused by a mutation acquired during growth in vitro, but reflects an in vivo abnormality. The lack of HLA class I antigen expression may have provided the mutant clone with a mechanism to escape from lysis by HLA class I cytotoxic T cells. The abnormality in $\beta_{2}-\mu$ is likely to reflect a somatic mutation during tumor progression, since the allospecificities HLA-A1, Aw33, B5, B14, Bw4, Bw6 were detected on patient's lymphocytes by using the complement-dependent cytotoxic assay (unpublished results). Immunohistochemical techniques could not be used to prove the lack of HLA class I antigens in the melanoma lesion, since only the formalin-fixed, paraffin-embedded tissue was available. Anti $\beta_{2}-\mu \mathrm{mAbs}$ reacting with formalin-fixed, paraffinembedded tissues are not available to us. Furthermore, mAbs recognizing determinants expressed only on $\beta_{2}-\mu$ associated HLA class I heavy chains stain only frozen tissue sections.

The clinical course of patient AZ was more favorable than expected, although tumor progression in patients with metastatic melanoma can be variable (52). The estimated 5-yr survival was $<20 \%$, based on the presence of extensive regional metastases. If the lack of HLA class I antigen expression by melanoma cells played a role in the clinical course of the disease in this patient, two contrasting scenarios may be envisioned. Loss of HLA class I antigen expression could have selected for a clone of $\mathrm{AZ}$ melanoma cells that escaped immune recognition by HLA class I-restricted cytotoxic T lymphocytes. If so, surgery removed all melanoma cells lacking HLA class I antigens. Alternatively, lack of HLA class I antigen expression could have enhanced the susceptibility of AZ melanoma cells to NK cell-mediated lysis, thus facilitating the clearance of residual melanoma cells after the surgical excision of nodal metastases. We favor the latter possibility, since in preliminary experiments we have found a reduction in susceptibility to NK cell-mediated lysis of melanoma cells SK-MEL-33 associated with the induction of HLA class I antigens by transfection with a wild-type human $B_{2} m$ gene.

\section{Acknowledgments}

The authors thank Dr. M. D. Poulik, Wm. Beaumont Hospital, Royal Oak, MI for providing $\beta_{2}-\mu$ and an anti- $\beta_{2}-\mu$ antiserum; Dr. N. Tanigaki, Roswell Park Memorial Institute, Buffalo, NY for providing a rabbit anti-HLA antiserum; and Dr. H. L. Ploegh, The Netherlands Cancer Institute, Amsterdam, The Netherlands and Dr. S. M. Weissman, Yale University School of Medicine, New Haven, CT for providing Bzm gene clone and DNA probes. The authors acknowledge the excellent secretarial assistance of Mrs. Edwina L. Jones, Mrs. Harriett V. Harrison, Mrs. Donna D. James, and Miss Gail D. Price.

This investigation was supported by United States Public Health Service grants CA37907 and CA39559 awarded by the National Cancer Institute, Department of Health and Human Services, and by grant IM-554 awarded by the American Cancer Society. R. A. Zeff is an Established Investigator of the American Heart Association.

\section{References}

1. Ruiter, D. J., V. Mattijssen, E.-B. Broecker, and S. Ferrone. 1991. MHC antigens in human melanomas. Semin. Cancer Biol. 2:35-45.

2. Turco, M. C., M. De Felice, L. Corbo, G. Morrone, R. Mertelsmann, S. Ferrone, and S. Venuta. 1985. Regulatory role of a monomorphic determinant of HLA Class I antigens in T cell proliferation. J. Immunol. 135:2268-2273.

3. Taylor, D. S., P. C. Nowell, and J. Kornbluth. 1986. Functional role of HLA class I cell-surface molecules in human T-lymphocyte activation and proliferation. Proc. Natl. Acad. Sci. USA. 83:4446-4450.

4. Sunday, M. E., K. J. Isselbacher, S. Gattoni-Celli, and C. G. Willett. 1989. Altered growth of a human neuroendocrine carcinoma line after transfection of a major histocompatibility complex class I gene. Proc. Natl. Acad. Sci. USA. 86:4700-4704. 
5. Mukherji, B., N. G. Chakraborty, and M. Sivanandham. 1990. T-cell clones that react against autologous human tumors. Immunol. Rev. 116:33-62.

6. Ljunggren, H.-G., and K. Karre. 1990. In search of the 'missing self': MHC molecules and NK cell recognition. Immunol. Today. 11:237-244.

7. van Duinen, S. G., D. J. Ruiter, E. B. Broecker, E. A. van der Velde, C. Sorg, K. Welvaart, and S. Ferrone. 1988. Level of HLA antigens in locoregiona metastases and clinical course of the disease in patients with melanoma. Cancer Res. 48:1019-1025.

8. D'Urso, C. M., Z. Wang, Y. Cao, R. Tatake, R. A. Zeff, and S. Ferrone. 1991. Lack of HLA Class I antigen expression by cultured melanoma cells FOdue to a defect in $\mathrm{B}_{2} \mathrm{~m}$ gene expression. J. Clin. Invest. 87:284-292.

9. Poulik, M. D., and A. D. Bloom. 1973. $\beta_{2}$-microglobulin production and secretion by lymphocytes in culture. J. Immunol. 110:1430-1433.

10. Barnstable, C. J., W. F. Bodmer, G. Brown, G. Galfre, C. Milstein, A. F. Williams, and A. Ziegler. 1978. Production of monoclonal antibodies to group A erythrocytes, HLA and other human cell surface antigens-new tools for genetic analysis. Cell. 14:9-20.

11. Brodsky, F. M., W. F. Bodmer, and P. Parham. 1979. Characterization of a monoclonal anti- $\beta_{2}$-microglobulin antibody and its use in the genetic and biochemical analysis of major histocompatibility antigens. Eur. J. Immunol. 9:536545.

12. Lampson, L. A., and R. Levy. 1980. Two populations of Ia-like molecules on a human B cell line. J. Immunol. 125:293-299.

13. Pellegrino, M. A., A.-K. Ng, C. Russo, and S. Ferrone. 1982. Heterogeneous distribution of the determinants defined by monoclonal antibodies on HLA-A and B antigens bearing molecules. Transplantation (Baltimore). 34:1823.

14. Quaranta, V., M. A. Pellegrino, and S. Ferrone. 1981. Serologic and immunochemical characterization of the specificity of four monoclonal antibodies to distinct antigenic determinants expressed on subpopulations of human Ia-like antigens. J. Immunol. 126:548-552.

15. Matsui, M., M. Temponi, and S. Ferrone. 1987. Characterization of a monoclonal antibody-defined human melanoma-associated antigen susceptible to induction by immune interferon. J. Immunol. 139:2088-2095.

16. Temponi, M., T. Kageshita, F. Perosa, R. Ono, H. Okada, and S. Ferrone. 1989. Purification of murine IgG monoclonal antibodies by precipitation with caprylic acid: comparison with other methods of purification. Hybridoma. 8:8595.

17. Fraker, P. J., and J. C. Speck, Jr. 1978. Protein and cell membrane iodinations with a sparingly soluble chloroamide, 1,3,4,6-Tetrachloro-3a,6a-diphenylglycoluril. Biochem. Biophys. Res. Commun. 80:849-857.

18. Lindmo, T., E. Boven, F. Cuttitta, J. Fedorko, and P. A. Bunn, Jr. 1984. Determination of the immunoreactive fraction of radiolabeled monoclonal antibodies by linear extrapolation to binding at infinite anigen excess. J. Immunol. Methods. 72:77-89.

19. Nakamuro, K., N. Tanigaki, and D. Pressman. 1975. Common antigenic structures of HL-A antigens. VI. Common antigenic determinants located on the 33,000-Dalton alloantigenic fragment portion of papain-solubilized HL-A molecules. Immunology. 29:1119-1132.

20. Reisfeld, R. A., E. D. Sevier, M. A. Pellegrino, S. Ferrone, and M. D. Poulik. 1975. Association of HL-A antigens and $\beta_{2}$-microglobulin at the cellular and molecular level. Immunogenetics. 2:183-197.

21. Suggs, S. V., R. B. Wallace, T. Hirose, E. H. Kawashima, and K. Itakura. 1981. Use of synthetic oligonucleotides as hybridization probes: isolation of cloned cDNA sequences for human $\beta_{2}$-microglobulin. Proc. Natl. Acad. Sci. USA. 78:6613-6617.

22. Sood, A. K., D. Pereira, and S. M. Weissman. 1981. Isolation and partial nucleotide sequence of a cDNA clone for human histocompatibility antigen HLA-B by use of an oligodeoxynucleotide primer. Proc. Natl. Acad. Sci. USA. 78:616-620.

23. Gussow, D., R. Rein, I. Ginjaar, F. Hochstenbach, G. Seemann, A. Kottman, and H. L. Ploegh. 1987. The human $\beta_{2}$-microglobulin gene. Primary structure and definition of the transcriptional unit. J. Immunol. 139:3132-3138.

24. Feinberg, A. P., and B. Vogelstein. 1984. Addendum: a technique for radiolabeling DNA restriction endonuclease fragments to high specific activity. Anal. Biochem. 137:266-267.

25. Geliebter, J., R. A. Zeff, R. W. Melvold, and S. G. Nathenson. 1986. Mitotic recombination in germ cells generated two major histocompatibility complex mutant genes shown to be identical by RNA sequence analysis: $\mathrm{K}^{\text {bm9 }}$ and $\mathrm{K}^{\mathrm{bm6}}$. Proc. Natl. Acad. Sci. USA. 83:3371-3375.

26. Zweig, S. E., and E. M. Shevach. 1983. Production and properties of monoclonal antibodies to guinea pig Ia antigens. Methods Enzymol. 92:66-85.

27. Laemmli, U. K. 1970. Cleavage of structural proteins during the assembly of the head of bacteriophage T4. Nature (Lond.). 227:680-685.

28. Bonner, W. M., and R. A. Laskey. 1974. A film detection method of tritium-labelled proteins and nucleic acids in polyacrylamide gels. Eur. J. Biochem. 46:83-88.

29. Geliebter, J., R. A. Zeff, D. H. Schulze, L. R. Pease, E. H. Weiss, A. L. Mellor, R. A. Flavell, and S. G. Nathenson. 1986. Interaction between $K^{\mathrm{b}}$ and Q14 gene sequences generates the $K^{\mathrm{bm} 6}$ mutation. Mol. Cell. Biol. 6:645-652.

30. Shibata, D. K., N. Arnheim, and W. J. Martin. 1988. Detection of human papilloma virus in paraffin-embedded tissue using the polymerase chain reaction. J. Exp. Med. 167:225-230.

31. Shibata, D., W. J. Martin, and N. Arnheim. 1988. Analysis of DNA sequences in forty-year-old paraffin-embedded thin-tissue sections: a bridge between molecular biology and classical histology. Cancer Res. 48:4564-4566.

32. Perbal, B. 1988. Purification of high molecular weight cellular DNA. In A Practical Guide to Molecular Cloning. B. Perbal, editor. John Wiley and Sons, New York. 324-326.

33. Zeff, R. A., M. Nakagawa, H. Mashimo, J. Gopas, and S. G. Nathenson. 1990. Failure of cell surface expression of a Class I major histocompatibility antigen caused by somatic point mutation. Transplantation (Baltimore). 49:803-808.

34. Saiki, R. K., S. Scharf, F. Faloona, K. B. Mullis, G. T. Horn, H. A. Erlich, and N. Arnheim. 1985. Enzymatic amplification of $\beta$-globin genomic sequences and restriction site analysis for diagnosis of sickle cell anemia. Science (Wash. DC). 230:1350-1354

35. Del Sal, G., G. Manfioletti, and C. Schneider. 1989. The CTAB-DNA precipitation method: a common mini-scale preparation of template DNA from phagemids, phages or plasmids suitable for sequencing. Biotechniques. 7:514520 .

36. Sanger, F., S. Nicklen, and A. R. Coulson. 1977. DNA sequencing with chain-terminating inhibitors. Proc. Natl. Acad. Sci. USA. 74:5463-5467.

37. Tabor, S., and C. C. Richardson. 1987. DNA sequence analysis with a modified bacteriophage T7 DNA polymerase. Proc. Natl. Acad. Sci. USA. 84:4767-4771.

38. Poulik, M. D., S. Ferrone, M. A. Pellegrino, D. E. Sevier, S. K. Oh, and R. A. Reisfeld. 1974. Association of HL-A antigens and $\beta_{2}$-microglobulin: concepts and questions. Transplant. Rev. 21:106-125.

39. Ploegh, H. L., H. T. Orr, and J. L. Strominger. 1981. Major histocompatibility antigens: the human (HLA-A, $-\mathrm{B},-\mathrm{C}$ ) and murine (H-2K, H-2D) Class I molecules. Cell. 24:287-299.

40. Parham, P , C. J. Barnstable, and W. F. Bodmer 1979. Use of a monoclonal antibody (W6/32) in structural studies of HLA-A, B, C antigens. J. Immunol. 123:342-349.

41. Bjorkman, P. J., M. A. Saper, B. Samraoui, W. S. Bennett, J. L. Strominger, and D. C. Wiley. 1987. Structure of the human class I histocompatibility antigen, HLA-A2. Nature (Lond.). 329:506-512.

42. Gates, F. T., III, J. E. Coligan, and T. J. Kindt. 1981. Complete amino acid sequence of murine $\beta_{2}$-microglobulin: structural evidence for strain-related polymorphism. Proc. Natl. Acad. Sci. USA. 78:554-558.

43. Goodfellow, P. N., E. A. Jones, V. van Heyningen, E. Solomon, M. Bobrow, V. Miggiano, and W. F. Bodmer. 1975. The $\beta_{2}$-microglobulin gene is on chromosome 15 and not in the HL-A-region. Nature (Lond.). 254:267-269.

44. Fountain, J. W., S. J. Bale, D. E. Housman, and N. C. Dracopoli. 1990. Genetics of melanoma. Cancer Surv. 9:645-671.

45. de Preval, C., and B. Mach. 1983. The absence of $\beta_{2}$-microglobulin in Daudi cells: active gene but inactive messenger RNA. Immunogenetics. 17:133140.

46. Rosa, F., H. Berissi, J. Weissenbach, L. Maroteaux, M. Fellous, and M Revel. 1983. The $\beta_{2}$-microglobulin mRNA in human Daudi cells has a mutated initiation codon but is still inducible by interferon. EMBO (Eur. Mol. Biol. Organ.) J. 2:239-243.

47. Hyman, R., and V. Stallings. 1976. Characterization of a $\mathrm{TL}^{-}$variant of a homozygous $\mathrm{TL}^{+}$mouse lymphoma. Immunogenetics. 3:75-84.

48. Parnes, J. R., K. C. Sizer, J. G. Seidman, V. Stallings, and R. Hyman. 1986. A mutational hot-spot within an intron of the mouse $\beta_{2}$-microglobulin gene. EMBO (Eur. Mol. Biol. Organ.) J. 5:103-111.

49. Parnes, J. R., and J. G. Seidman. 1982. Structure of wild-type and mutant mouse $\beta_{2}$-microglobulin genes. Cell. 29:661-669.

50. DeMars, R., R. Rudersdorf, C. Chang, J. Petersen, J. Strandtmann, N. Korn, B. Sidwell, and H. T. Orr. 1985. Mutations that impair a posttranscriptional step in expression of HLA-A and -B antigens. Proc. Natl. Acad. Sci. USA. 82:8183-8187.

51. Spies, T., M. Bresnahan, S. Bahram, D. Arnold, G. Blanck, E. Mellins, D. Pious, and R. DeMars. 1990. A gene in the human major histocompatibility complex class II region controlling the class I antigen presentation pathway. $\mathrm{Na}$ ture (Lond.). 348:744-747.

52. Balch, C. M., A. N. Houghton, and L. Peters. 1990. Cutaneous melanoma. In Cancer: Principles and Practice of Oncology. V. T. DeVita, S. Hellman, and S. A. Rosenberg, editors. J. B. Lippincott, Philadelphia. 1499-1542. 